U poglavlju „Povezivanje nastavnih sadržaja“ opisuje se korelacija u nastavi koja podrazumijeva povezivanje odgojno-obrazovnoga procesa u skladnu cjelinu. Iznose se primjeri povezivanja sadržaja unutar istoga obrazovnoga područja (unutarpredmetna korelacija) i spajanja različitih predmetnih područja (međupredmetna korelacija), uz prikaz primjera integriranoga dana.

Navodeći kako ,[s]voj današnji status ova disciplina može zahvaliti predanom radu brojnih hrvatskih metodičara” (226), autor uvodi čitatelja u poglavlje „Pregled povijesti metodike hrvatskoga jezika“. Osvrt obuhvaća činjenični prikaz hrvatskoga školstva u 19. stoljeću s naznakom djelovanja i doprinosa uglednih metodičara hrvatskoga jezika i književnost do šezdesetih godina 20. stoljeća i nakon šezdesetih godina 20. stoljeća. U potpoglavljima je pomoću metodičkih krugova prikazan sveučilišni regionalizam suvremene hrvatske metodike te metodički prinosi znanstvenika i stručnjaka iz srodnih odgojno-obrazovnih područja.

Temeljem sadržajnoga razmatranja i uvida u opsežan broj referiranih bibliografskih podataka, izvora i literature može se zaključiti da je djelo sveobuhvatno, utemeljeno na stručnim i znanstvenim načelima te da prikazuje najvažnije sadržaje metodike hrvatskoga jezika. Budući da je predmetno područje Hrvatskoga jezika složeno, a i sama znanost o poučavanju predmeta slojevita, u knjizi se očituje interdisciplinarnost znanstvene dimenzije i pojmovnoga razmatranja. Izabrani predlošci, rezultati istraživanja navođenih autora i posebice prikazani metodički modeli razrade nastavnih sati pružaju dobru osnovicu za uspostavljanje unutarpredmetnih i međupredmetnih suodnosa nastavnih sadržaja. Knjiga uključuje primjere koji pokazuju funkcionalnost teorijskih polazišta u praksi i koji će zasigurno pomoći čitateljima u primjerenoj recepciji i primjeni njezinih postavki u nastavi.

Petra Pejić Papak

\title{
Oblici konceptualne proze: poetike hipertekstualnosti
}

\section{Andrijana Kos-Lajtman. 2016. Poetika oblika: suvremene konceptualne i hiper- tekstualne proze. Zagreb: Naklada Ljevak. 288 str. ISBN 978-953-303-920-6}

DOI: 10.21066/carcl.libri.2018-07(01).0011

Poetika oblika primjeren je naslov knjige koju je napisala Andrijana Kos-Lajtman. Riječ je o jednoj u nas podosta neuobičajenoj znanstvenoj temi: eksperimentalnoj i konceptualnoj prozi. Neuobičajenoj zbog teme, ne toliko zbog analiziranih romana u studiji, koliko zbog intencije da radikalnim književnim oblicima da primjereno mjesto u panteonu hrvatske proze. Knjiga je zanimljiva i zbog još nečega. Naime, u posljednje vrijeme svjedoci smo kako se na primjerima u suštini tradicionalnih pripovjednih modela primjenjuje teorijska ,teška artiljerija“. Kos-Lajtman radi obratno - prozu koju uzima za pomno čitanje, kompleksnu i složenu, recepcijski zahtjevnu, analizira s nevjerojatnom dozom svakojake mjere. Analitički, pregledno i razumno. Razumno, jer ne inzistira na razmetljivome pokazivanju teorijske kompetencije, nego svoj povijesni, komparatistički i teorijski inventar prilagođava interpretacijskomu horizontu, odnosno književnosti samoj.

Autorica svako poglavlje uzorno strukturira, neovisno o tome je li riječ o dječjoj književnosti, teorijskim problemima ili romanima Jasne Horvat. Prvo u fokus stavlja 
određeni pojam/fenomen bitan za daljnju analizu, nakon toga daje njegov historijat $\mathrm{u}$ stručnoj literaturi s najvažnijim i najnužnijim deskripcijama, a u konačnici sintetizira ga do razine vlastite uporabne prakse. Time se uspostavlja preglednost, teorijska, povijesna i analitička. A tema joj je teška i široj publici neomiljena: konceptualna i hipertekstualna proza. Stvar dodatno „komplicira“ uvodeći u rječnike književnih termina novi pojam: „lematizirana proza“. Stoga je takav strukturirani pristup primjeren jer joj je predmet analize (lematizirana proza) složena narativna struktura koja počiva na izbjegavanju linearnosti, a naglašavanju hibridnosti i različitih tipova fragmentarnosti u osnovi kojih je ideja otvorenoga djela, nedovršenost i(li) mogućnost nadopisivanja.

Pojam lematizacije proze autoričin je terminološki neologizam, premda posuđen iz leksikografije, kojim će pristupiti pomnomu čitanju, prije svega, romana Jasne Horvat. Što je to, prema Kos-Lajtman, lematizirana proza? U proznim strukturama koje se još uvijek tiskaju (,,protohipertekst“) i onima u digitalnome obliku (,hipertekst“") zajednička je ideja razbijanje klasičnoga, linearnoga narativnoga slijeda. Uz njih postoje i tipovi naracije koji inzistiraju na kronološkim sljedovima karakterističnim za znanost i leksikografiju. U navođenju primjera „lemske književnosti“ (Hazarski rečnik Milorada Pavića, Rječnik uvriježenih mnijenja Gustavea Flauberta, Enciklopedija ništavila Stanka Andrića itd.), KosLajtman kreće od književnosti prema njezinoj leksikografsko-znanstvenoj diskurzivnosti. Pritom bi trebalo navesti i obrnuti primjer u kojem, u Ogledu o podrupku, Milorad Stojević kreće od stroge znanstvene akribije kako bi manifestirao književnu ideju, a zapravo parodirao znanost i književnost podjednako.

Prvi je autoričin posao, dakle, terminološko parceliranje, preciziranje, usložnjavanje, a potom i povijesno kontekstualiziranje navedenoga književnoga modela. Biblija se navodi kao jedan od prvih primjera lematizirane književnosti. Prilikom diobe na podtipove lematiziranoga romana Kos-Lajtman prepoznaje: roman slovarij, roman rječnik, roman paukove mreže, roman s dodanim tematskim leksikonom, roman udžbenik, te roman lažnoga naslova. Sve te podvrste romana pritom označava kao konceptualne i postmodernističke. Sam pojam konceptualnosti detaljnije ne obrazlaže već preuzima najširi i opći opis, i to od Krešimira Bagića, koji se, u opisu sustava konceptualne književnosti, poziva na klasičnu strukturalističku dihotomiju (dijalektičku napetost) koja govori o jedinstvu forme i sadržaja, odnosno o smislotvornosti forme i oblikotvornosti sadržaja. Pritom ne gradi razliku, pojmovnu, prema terminološkim imenovanjima Cvjetka Milanje u knjizi Hrvatski roman 1945.-1990., tako da je taj dio pomalo „koncepcijski““ zanemaren. Zapravo, govorimo li o postupcima u kojima znak sliči predmetu, možemo primijetiti da ima prostora i za promišljanje o pojmu ,ikonički roman“ za koji se ipak ne odlučuje, premda ga je itekako svjesna. O njem je autorica već pisala u jednome američkome časopisu (,A New Conceptuality in Contemporary Croatian Novels: The Novels of Jasna Horvat as Iconic Concepts“, Journal of Croatian Studies, vol. XLIX, 2008.). Iz toga se primjera vidi sva problematika terminološke nominacije, osobito kada postoje preklapanja u semantičkome polju.

U prvome, teorijskome dijelu knjige, Kos-Lajtman postavlja okvir koji joj je potreban za analizu romana Jasne Horvat, koju pak provodi u drugome dijelu. Okvir je sljedeći: lematizirana i hipertekstualna proza kao nadređeni termini koji se detaljnije, na nižoj razini, opisuju u društveno-tehnološkoj paradigmi mreže/interneta te književnome kontekstu - 
dječjoj književnosti, kao i onoj namijenjenoj odraslijoj publici. Autorica primjećuje kako se lematizirana proza pojavljuje za oba tipa publike, dakle i u dječjoj književnosti postoji prava i popratna lematizacija te ona koja je simbioza obaju prethodno navedenih tipova. Pravu lematizaciju prepoznaje u tekstovima Zvonimira Baloga te Stanislava Marijanovića, dok za nepravu navodi primjere: Pustolovine morskog konjica Tomislava Marijana Bilosnića, Krijesnike Jasne Horvat te roman Moji grafiti autora Roberta Mlinareca, Ratka Bjelčića i Vladimira Bakarića. Usto, dječja lematizirana proza i vremenski prati postmodernističku književnost za odrasle, štoviše ona to i jest. Kako sama autorica navodi: „Gotovo da bi se moglo reći da su upravo takvi, lematizirani diskursi paradigmatski primjeri postmodernizma $\mathrm{u}$ dječjoj književnosti, tj. da prezentiraju velik broj karakterističnih obilježja i strategija postmodernističkih poetika“" (143-144.). Zanimljivo je da autorica ne pravi razliku u teorijskome pristupu tekstovima namijenjenima „,velikoj“ i „maloj“ publici, štoviše, dokazuje da je struktura teksta ista, a tek sadržaji različiti.

U daljnjoj potpodjeli autoricu zanimaju tipovi, diskurzi leksikografske metodologije, odnos lema i leksije, tipovi lemske proze itd. Zapravo, Poetika oblika pokušaj je da se unutar kontradiktornoga pojma postmoderne i postmodernizma opišu neoavangardne, eksperimentalne, pa i konceptualne književne prakse.

Autorica iscrpno upućuje na specifično potenciran odnos postmodernističke književnosti prema različitim znanjima: historiografskim, politološkim, teološkim, filozofskim. O hibridnosti takvih žanrova, na što upućuje Julija Kristeva, suština kojih se može svesti na tekstualnost koja se pisanjem iznova čita, ne treba posebno ni govoriti. Intertekstualnost se potvrđuje u neautentičnome stilu koji zovemo postmodernizam kao ona instancija kojoj je osnovna funkcija potenciranje višeznačnosti, multidiskurzivnosti, kodiranosti i sl. Ukoliko je Borgesova idealna karta svijeta u omjeru 1:1 naspram svijeta, utoliko tu ikoničku znakovnu prekrivenost danas preuzima sveprisutna „mreža“ sa svojom naracijom suvremenosti koje su, iz pozicije cyberspacea: dualizam realno-virtualno, prirodatehnologija, materijalno-nematerijalno (digitalno). Karta = mreža, od materijalnoga znaka na papiru do nematerijalnoga digitalnoga znaka sa zajedničkom funkcijom - prekrivanje svijeta. „[I] većina naših simboličkih podražaja stiže iz medija“ (Informacijsko doba: ekonomija, društvo i kultura. Uspon umreženog društva, 364) zaključuje Manuel Castells; zar ne bi onda bilo prirodno očekivati i literaturu koja će intenzivnije komunicirati upravo s prevladavajućim medijem interneta i virtualne stvarnosti? Ako su prošlost i sadašnjost na mreži lišeni temporalnosti, uvijek prisutni i prezentni, zar onda načelo slobode, ludizma, demokratičnosti, nesvrhovite kreativnosti ne bi bilo primjereno ne samo umjetnosti općenito, nego još više onoj koja smjera biti konceptualnom, istraživačkom, inovativnom, kao što sugerira Kos-Lajtman? A to nas vodi, tvrdi autorica, prema hiperfikciji i njezinu izrazu - hipertekstu. Bez obzira što mreža, ,zafrkava“ se Julian Barnes u Flaubertovoj papigi, može biti i ,zbirka rupa povezanih nitima“ (37).

„Zafrkancija“ često preuzima masku ozbiljnosti. Između ostalih maski, jedna od uvjerljivijih jest znanost o književnosti. Rekao bih da je toga svjesna autorica Poetike oblika. Kada se nerv za čitanje ludističnih, pomaknutih, meta/inter/tekstualnih/medijalnih knjiga prikopča na ozbiljan/,ozbiljan“ diskurz znanosti, rezultat je odmjeren i svi su na dobitku - i teorija i književnost. Fina je to i mnoštvena simulacija položaja i pogleda kojoj jedino nedostaje povijest književnosti da bi bila potpunijom (v. npr. romane Milorada 
Stojevića, Tomislava Ladana, Marina Carića itd.). Konceptualni okvir romana Jasne Horvat jest književnost OULIPA (Ouvroir de littérature potentielle, Radionica potencijalne književnosti), nama najpoznatijih književnika Itala Calvina, Georgesa Pereca te Raymonda Queneaua.

No, možda povijesni aspekt izostaje, ali ne i komparatistički. Paralelnim čitanjima Jasne Horvat s Miloradom Pavićem, Dževadom Karahasanom ili Venkom Andonovskim, uspostavlja se literarno ,pobratimstvo lica u svemiru“. Jedino je i moguće, a i razumno, čitati s jedne strane hrvatsku književnost u kontekstu europskih iskustava, a s druge, staviti nas u logičan jezični areal onoga što zovemo regionalnom ili južnoslavenskom književnošću. Budući da postmodernizam inzistira na razlikama, Kos-Lajtman se fino poigrala u Poetici oblika i ukazala na sličnosti te na idejne bliskosti različitih eksperimentu sklonih književnika, bez obzira na to gdje obitavali. Ideja mreže stoga nije zbirka rupa nego nit vodilja koja u različitim kulturama nitima povezuje radikalne oblike mašte, ludizma, invencije.

Sanjin Sorel

\section{Die spezifische Ausprägung des Initiationsromans in der Kinderliteratur}

Hadassah Stichnothe. 2017. Der Initiationsroman in der deutsch- und englischsprachigen Kinderliteratur. Heidelberg: Universitätsverlag Winter. 300 Seiten. ISBN 978-3-8253-6766-4

DOI: 10.21066/carcl.libri.2018-07(01).0012

Auf Grundlage seiner Beschäftigung mit dem modernen amerikanischen Roman stellte Peter Freese in seinem Werk Die Initiationsreise. Studien zum jugendlichen Helden im modernen amerikanischen Roman mit einer exemplarischen Analyse von J. D. Salingers ,, The Catcher in the Rye “ fest, dass Initiationsromane des 20. Jahrhunderts „verwirrte und suchende Heranwachsende in [...] prekäre[r] Grenzstellung zwischen der noch nicht verlorenen Unschuld des Kindes und der noch nicht gefundenen Erfahrung der Erwachsenen, [die] den Übergang von der einen Welt in die andere [...] leisten, den Fall durch Wissen zur Reife [...] erleiden, [...] um initiation zu leisten, [...]" thematisieren (1971: 23-24). Neulich (2014) beschäftigte sich Nicole Gast mit dem Reifewerden im neueren deutschen Roman in ihrer Dissertation Erwachsenwerden im deutschen Pop-Roman. Der Reifeprozess der Protagonisten in Faserland, Soloalbum \& Co. Eine vergleichende Studie deutsch- und englischsprachiger Initiationsromane präsentiert dagegen Hadassah Stichnothe, indem sie in ihrer Dissertation Der Initiationsroman in der deutsch- und englischsprachigen Kinderliteratur die spezifische Ausprägung des Initiationsromans in der Kinderliteratur thematisiert. Der Band ist 2017 in der Serie Studien zur europäischen Kinder- und Jugendliteratur/Studies in European Children's and Young Adult Literature erschienen.

Stichnothes formal aus zwei Teilen bestehende Monografie ist strukturell in sieben inhaltliche Einheiten gegliedert, wobei der erste Teil die theoretische Grundlage und der längere zweite Teil die aus verschiedenen Perspektiven und auf verschiedene Themen bezogenen Textanalysen beinhaltet. Ähnlich wie Gast (2014) setzt sich Stichnothe mit dem anthropologischen und literaturwissenschaftlichen Begriff Initiation und der Erörterung 